\title{
A NOTE ON THE ELIZABETHAN SANITARY GODE
}

\author{
by
}

\section{JOHN SIMPSON}

Edwin Chadwick's 'Report on the Sanitary Conditions of the Labouring Population of Great Britain' in 1842 focussed attention on the frightful conditions of the cities and struck the first blow for modern public health. [Leavell and Clark, 1953.]

The influence of Chadwick on the public health movement and the association of the 'sanitary idea' with his name has tended to obscure the fact that sanitation and a sanitary code existed in the pre-Chadwick era. It is unnecessary to go further back than the Elizabethan period for an example of a comprehensive sanitary code; and in looking at the development of health activities in Tudor England it is apparent that such development was contingent upon the growth of a strong centralized government. This State attitude was most developed during Elizabeth's reign when regulation of industry, and of other phases of economic life, was the accepted order. This situation is in complete contrast to conditions during the early nineteenth century when the relative independence of agrarian life was lost in the overcrowded cities.

Under the new industrialisation, the lot of the wage-labourer was hardly a happy one. While the peasant or rural artisan of the eighteenth century had most likely worked long hours and been ill-housed and ill-clad, he had been, to a considerable degree, his own master. He often owned some land, some tools and a cottage. He had some security. He was part of a friendly community that felt some responsibility for him. The worker in the factories, forges and mines of the 1840 's had few such advantages. He laboured twelve to fourteen hours a day at a machine in dismal, unsanitary and unsafe factories. If he was a miner he worked underground and scarcely saw the light of day. He went to work at the sound of a whistle. He was fined for absence or lateness. He was clad in rags or shoddy cloth. He ate unwholesome food. He lived in a rented room in some sort of human rabbit-warren with much dirt and little or no sanitation. His work was intensely monotonous and he had few amusements. He was often unemployed because the factory owner found it cheaper to hire his wife and children. Even six-year-olds were found useful because of their nimble fingers. . . .

In earlier rural life, there had always been work to do. But in the newer industrial life there were jobless men-the unemployed. And every few years, there recurred a business 'crisis' or 'depression' that produced widespread mass unemployment with intense suffering for the hapless urban proletarians. [Hayes and Cole, 1949.]

This contrasts markedly with the reign of Elizabeth which is usually regarded as prosperous, although she had inherited a legacy of pauperism from her father Henry VIII and from her father's counsellors who had guided the young Edward VI. Social discontent had been prevalent at her accession, but due to the growth of wealth and industry throughout the Kingdom, due to the rapid expansion of manufactured goods and due to gains in foreign trade, the bulk of the people became contented and comfortable (Gibbins, I890). 


\section{Population Growth}

At the time of Domesday the population of England was under two millions, and when Edward III's poll-tax was levied in I 377 the population was not more than two and a quarter millions but by the end of Elizabeth's reign it had risen rapidly to some five million persons at which figure it remained for a further century and a half. The bulk of the population lived in the southern half of the Kingdom although the north was now becoming more prosperous owing to the extension of manufactures; England was by no means overcrowded but some did complain of this population increase.

Some also do grudge at the great increase of people in these days, thinking a necessary brood of cattle far better than a superfluous augmentation of mankind. [Harrison, 1577.]

The effect of this population increase caused London to encroach more rapidly on the open country.

Without the Aldgate bars both sides of the street be pestered with cottages and alleys, even up to Whitechapel Church and almost half-a-mile beyond it, into the common field; all of which ought to be open. [Stow, I598.]

The medieval timber-built city of gables and steep red-tiled roofs has a picturesque quality which tends to obscure the reality. The thin framework of the timber-built houses was filled in with laths and made rain-tight with roughcast plaster, but the houses were damp (Bell, 1924). This method of frame building should have afforded ample opportunity for good lighting, but the rooms behind the attractive casement-windows were dark and low. The house drained, if at all, into a cesspool, and was rat-ridden as a matter of course.

This crowding of the population into the outskirts of London was of grave concern to the government as it appreciated the danger from disease in such congested areas. In a Royal Proclamation of 1580 , Elizabeth had this to say:

The Queen's Majesty perceiving the state of the City of London and the suburbs and confines thereof to increase daily by access of people brought to inhabit the same ... and there are such great multitudes of people brought to inhabit in small rooms, whereof a great part are seen to be very poor; yea such must live as begging, or of worse means; and they heaped up together, and in a sort smothered with many families of children and servants in one house or small tenement; it must needs follow, if any plague or popular sickness should by God's permission enter among those multitudes, that the same should not only spread itself and invade the whole city and confines, as great mortality should ensue the same, but would be dispersed through all other parts of the realm to the manifest danger of the whole body thereof. [Bell 1924.]

This was the first of many futile efforts to restrict the size of the capital and this particular law was designed to prohibit new building within the city area and the subdivision of existing houses into tenements.

As a result of this population increase the problem of an adequate food supply in times of shortage became a serious one, and in 1577 John Dee, the royal physician, suggested that the Government establish stores of grain to meet such emergencies. This was done in a small way by several municipalities but in 276 


\section{A Note on the Elizabethan Sanitary Code}

I623 James I developed this plan on a large scale. He hoped to stabilize prices by storing corn in various parts of the country and in times of shortage to sell it at a fair and fixed price.

The value of pure wholesome food to health was well appreciated by the Elizabethans for the standards and the quality of food products were regulated by such laws as the 'Assize of Bread', and the Government proceeded vigorously against anyone selling bad or tainted food (Larkey, I934); and, by Royal Proclamation, Elizabeth said:

We must provide . . . food and other like necessaries for man's life upon reasonable prices without which no city can long continue.

... food should be good, sweet, sound and wholesome for man's body.

The Plague Orders, too, make mention of food:

That care must be taken that no unwholesome meats, stinking fish, flesh, or musty corn, or other unwholesome food be exposed to sale in shops or markets. [Bell, 1924.]

\section{General Sanitary Measures}

A Commission of Sewers had been established as early as the fifteenth century by Henry VI. This provided severe penalties for the pollution of streams; and these were enforced. Tanners and brewers were required to drain their waste into cesspools and owners of swine had to provide suitable accommodation for their animals and take special precautions that there should be no drainage from the styes into neighbouring streams. In this connexion it is of interest to note that Henry VII recognized the menace to health from slaughterhouses and passed a law forbidding them within cities or towns, 'Lest it might engender sickness, unto the destruction of the people.' (Larkey, 1934.)

It was in the shambles of Aldgate that much of London's meat supply was killed; but, by the time of Elizabeth's accession, London had encroached upon Aldgate.

... is so encroached upon by building of filthy cottages, and with other purprestures, enclosures and laystalls (notwithstanding proclamations and Acts of Parliament to the contrary) that in some cases it scarce remaineth a sufficient highway for the meeting of carriages and droves of cattle, much less is there any fair, pleasant or wholesome way for people to walk on foot, which is no small blemish to so famous a city. [Stow, 1958.]

The uncleanliness of the city was considerable. Cardinal Wolsey, when passing about the town, had the habit of holding to his nose an orange, into which pungent spices had been inserted, in order to obscure the smell that filled the streets.

The unsanitary condition of the streets was considered an important factor in the spread of epidemic disease, especially plague; and the Plague Orders embodied a requirement for street cleaning:

... and that all publique places (especially streets and passages) be kept sweet and clean; and that all laystalls, dunghills and slaughterhouses near any dwellings be removed to places more remote. 


\section{John Simpson}

In wet weather the streets and alleys remained ankle-deep in mud, while in the wider ways rainwater streamed from the house roofs on to the cobblestones and out into the kennels. The value of fresh air and cleanliness of both person and home was little understood; and the confined wooden buildings, with projecting upper storeys that almost met over streets and courts of but a few feet width, prevented the healthy circulation of air.

Sanitary science, in the modern sense, was extremely rudimentary in the Elizabethan period. In medieval London, wherever there was running water, or even stagnant water, the 'houses of office' or closets were built over as affording the easiest way of performing the withdrawals now effected by water carriage and a system of drainage. Thus streams, such as the Fleet in London, were little more than open sewers. Even so, the general efforts of Elizabeth did much to improve conditions, in both town and country.

Thomas (1933) who has made a study of some twelve sixteenth-century English towns, has this to say:

If a wider knowledge of town life as revealed by town 'Records' refutes the view that towns remained filthy and entirely neglected by ignorant and irresponsible authorities so must a fuller acquaintance with the little that is known about the origin of the diseases of the sixteenth century modify the opinion that town conditions caused those diseases.

Thomas also made a comparison of the twelve towns in the sixteenth century with the conditions revealed in them by the Royal Commission Survey I 844-5. He concludes that the towns were cleaner in all respects, and were healthier, in the sixteenth century. If some period in town life must be labelled as a time of insanitation, then the nineteenth century should be chosen.

\section{The Plague}

One of the most important public health functions of the Government was the control of epidemic disease. From an early part of the sixteenth century the medical profession played a prominent part through the College of Physicians which had been founded in 1518 by Henry VIII on the advice of his physician, Thomas Linacre. It is, perhaps, significant that from that year date some significant public health measures such as the isolation and marking of houses infected with Plague, the isolation of clothes and goods of those dying of Plague, the first Plague Orders and the first Bills of Mortality.

The Great Plague of 1665 has so concentrated popular attention that the frequency of Plague has largely escaped notice. Plague was no stranger to London; indeed, from I603, when weekly Bills of Mortality were introduced, until 1665 , only four widely separated years had been free from any recorded epidemic. In 1603 , the year Elizabeth died, there were 33,347 recorded Plague deaths in London. In 1563 , during a particularly severe Plague epidemic, Elizabeth retreated to Windsor, and set up a gallows in the market place on which to hang all Londoners who should venture there.

For the control of Plague two sets of Orders were issued, one for London and one for the rest of the country. The provisions of each were the same, it was the 278 


\section{$A$ Note on the Elizabethan Sanitary Code}

administrative authority which differed: in London, authority was vested in the Lord Mayor and Aldermen; in the country, in the Justices of the Peace. The Orders also required the raising of funds by taxation and the money thus raised was to be used both for general measures against the Plague and for the provision of food, fuel, and medicine for those isolated due to Plague or the suspicion of Plague.

The advisability of segregating Plague cases had occupied the ruling authorities for some time. In Henry VIII's reign this had been done by enclosing them in the infected houses and the doors marked. In Elizabeth's reign more was considered necessary and pest-houses were established both in London and in the country. The magistrates had power to remove Plague victims to these pest-houses; and by this means the few sporadic cases which occurred in uneventful years were kept in check and were prevented from spreading the disease. Such provision was never adequate and no sooner did an epidemic break out than the old panic-measure of locking up the sick and the healthy together in their homes was resumed.

Public gatherings of people at plays, bear-baitings, and fairs were forbidden, schools were closed and preparations were made for the burial of the dead in a place apart. The clothes, bedding, and other goods of those dying or recovering from the Plague were usually burned and the owner recompensed from the general funds.

It was well recognized that the poor would have difficulty in obtaining and paying for medical attention; the Plague Orders required universal medical care: 'by the best learned in Physicke within this Realme ... and without charge to the meaner sort of people'. The College of Physicians organized this Plague service on a permanent footing and so created the first Public Health Physicians. These men were bound by oath to remain at their posts, and many died of the Plague (Larkey, I934).

The organization outlined in the Plague Orders did much to check the spread of the disease but since the cause of the disease, and the means of transmission, were unknown, its eradication was not possible. The disease was endemic and from time to time exploded into devastating epidemics. It was rare for more than two decades to pass without a severe epidemic. In I 499 a severe epidemic in London caused Henry VII to retire to Calais. In a register of burials of the City church of St. Peter Cornhill, at the close of the entries for the year 1593 are these lines:

In a thousand five hundred ninety and three
The Lord preserved my house and mee
When of the pestilence theare died
Full manie a thousand els beeside

[Bell, 1924]

During epidemics the people became panic-stricken and the control-system broke down; the Orders could not be enforced, the dead were left unburied, and the doctrine of sauve qui peut became universal. It is this human factor 


\section{John Simpson}

which is the most difficult element in the administration of general control measures; and this factor becomes the more ungoverned given medieval traditions concerning contagion and the causes of epidemics.

In general, however, there developed during the Elizabethan period those ideas of the State's direct concern with the health of its citizens which are the basis of our modern public health organization. The methods of public health supervision devised by the Elizabethans were fundamentally sound and form the basis of our modern system which, with increased scientific knowledge of disease, have almost freed the world from epidemic disease.

\section{REFERENCES}

BeLL, W. G. (1924). The Great Plague in London in 1665. London, The Bodley Head. HAYes, G. J. H. and Cole, C. W. (1949). History of Europe since 1500. London, Macmillan.

Gi B B I Ns, W. DE B. (189o). The Industrial History of England. London, Methuenand Co. HARrison, W. (1577). Elizabethan England. Ed. by L. Withington. London, Walter Scott.

Larkey, S. V. (1934). Amer. F. Publ. Hlth., 24, 912 and 1099.

Leavell, H. R. and Glark, E. G. (1953). Textbook of Preventive Medicine. New York, McGraw-Hill.

STow, J. (1598). Surveigh of London, quoted by Bell, W. G. in The Great Plague in London in 1665. London, The Bodley Head.

Tномаs, J. H. (1933). Town Government in the Sixteenth Century. London, Allen and Unwin. 